Akreditasi KEMENRISTEKDIKTI, Nomor: 148/M/KPT/2020
hettp: / /jurnal.stkippersada.ac.id/jurnal/index.php/VOX

\title{
PENGEMBANGAN BAHAN AJAR KOMIK MUATAN MATEMATIKA MATERI SATUAN BERAT DI SEKOLAH DASAR
}

\author{
Wiwik Widia Sari ${ }^{1}$, \& Rudi Ritonga ${ }^{2}$ \\ ${ }^{1,2}$ Fakultas Keguruan dan Ilmu Pendidikan, Universitas Trilogi \\ Email:widiawiwik2@gmail.com ${ }^{1}$, rudi_ritonga@trilogi.ac.id ${ }^{2}$
}

\begin{tabular}{|c|c|}
\hline INFO AR & TIKEL \\
\hline Riwayat $A$ & tikel: \\
\hline Menerima & : 28 Agustus 2021 \\
\hline Revisi & : 13 September 202 \\
\hline Diterima & : 17 September 202 \\
\hline
\end{tabular}

\section{Kata Kunci:}

Pengembangan, bahan ajar komik, minat belajar

\section{Keywords:}

Development, comics teaching materials, interest in learning.

Korespondensi:
Wiwik Widia Sari
Fakultas Keguruan dan Ilmu
Pendidikan, Universitas Trilogi
Email:
Widiawiwik2@gmail.com

Widiawiwik2@gmail.com

\begin{abstract}
ABSTRAK
Penelitian pengembangan ini dilakukan untuk menghasilkan produk bahan ajar komik matematika materi satuan berat yang bertujuan untuk memecahkan permasalahan pendidikan. Pengembangan bahan ajar komik matematika materi satuan berat ini dikembangkan sesuai dengan karakteristik dan kebutuhan siswa kelas II Sekolah Dasar. Penelitian ini peneliti menggunakan metode $\mathrm{RnD}$ model pengembangan Borg and Gall dalam (Sugiyono, 2012) yang dilakukan dengan 9 tahap, yaitu: (1) potensi dan masalah, (2) pengumpulan data, (3) desain produk, (4) validasi produk, (5) revisi produk, (6) uji coba produk, (7) revisi produk, (8) uji pemakaian produk, (9) revisi produk. Subjek pada penelitian ini ialah siswa kelas II SDN Pejaten Timur 18 Pagi Jakarta Selatan yang berjumlah 29 siswa. Data kuantitatif pada penelitian ini didapatkan dari hasil wawancara dan observasi. Data kuantitatif pada penelitian ini didapatkan dari hasil validasi serta kuesioner. Validasi bahan ajar mendapatkan nilai $86.83 \%$ dengan kategori sangat layak. Hasil nilai uji coba produk skala kecil yaitu 9 siswa mendapatkan nilai $92.89 \%$ dengan kategori sangat layak. Sedangkan hasil uji coba pemakaian produk skala besar yaitu 29 siswa mendapatkan nilai $89.72 \%$ dengan kategori sangat layak. Pengembangan produk berupa bahan ajar komik matematika materi satuan berat ini dinilai sangat layak dan efektif digunakan saat kegiatan pembelajaran. Penelitian selanjutnya diharapkan bisa mengembangkan bahan ajar komik matematika dengan berbagai materi agar lebih bervariatif.
\end{abstract}

\section{ABSTRACT}

This development research was conducted to produce a weight unit material for mathematics comics teaching materials that aim to solve educational problems. The development of mathematics comics teaching materials for weight units was developed according to the characteristics and needs of second grade elementary school students. In this study, researchers used the RnD method of the Borg and Gall development model in (Sugiyono, 2012) which was carried out with 9 stages, namely: (1) potential and problems, (2) data collection, (3) product design, (4) product validation, (5) product revision, (6) product trial, (7) product revision, (8) product usage test, (9) product revision. The subjects in this study were the second grade students of SDN Pejaten Timur 18 Pagi, South Jakarta, totaling 29 students. Quantitative data in this study were obtained from interviews and observations. Quantitative data in this study were obtained from the results of validation and questionnaires. The validation of teaching materials got a score of $86.83 \%$ with a very decent category. The results of the small-scale product trial scores, namely 9 students, got a score of $92.89 \%$ with a very decent category. While the results of trials using large-scale products, namely 29 students got a score of $89.72 \%$ with a very decent category. Product development in the form of math comics teaching materials for weight units is considered very feasible and effective to use during learning activities. Future research is expected to be able to develop mathematics comics teaching materials with various materials to make them more varied. 


\section{PENDAHULUAN}

Bahan ajar adalah sebuah pedoman yang sering dipakai oleh guru-guru untuk membantu pada kegiatan belajar mengajar di kelas (Lestari, 2018). Bahan ajar juga dapat membimbing saat kegiatan pembelajaran agar bisa tercapainya tujuan pembelajaran. Sedangkan untuk siswa bahan ajar dijadikan sebagai pedoman dan membantu siswa saat kegiatan pembelajaran. Pengertian lain dari bahan ajar merupakan suatu faktor yang paling penting untuk kegiatan belajar mengajar agar proses pembelajaran bisa efektif khususnya di Sekolah Dasar (Arsanti, 2018). Berdasarkan dari penjelasan tersebut lalu peneliti dapat merangkum yaitu bahan ajar ialah seperangkat pembelajaran untuk memfasilitasi serta memudahkan guru dan siswa ketika kegiatan pembelajaran dikelas.

Bahan ajar memiliki fungsi yaitu sebagai berikut: 1) pedomana untuk guru dalam mengarahkan siswa saat kegiatan pembelajaran di kelas, 2) pedoman untuk siswa dalam mempelajari materi, 3) sebagai alat evalusi pencapaian siswa, 4) membantu guru dalam mengajar, 5) membantu siswa dalam belajar, 6) sebagai perlengkapan dalam pembelajaran di kelas agar bisa mencapai tujuan pembelajaran, 7) menciptakan kegiatan pembelajaran yang kondusif dan efektif (Nurdyansyah \& Mutala'liah, 2016). Prinsip dalam pemilihan bahan ajar yaitu mencakup prinsip relevansi, konsistensi, dan kecukupan. Berikut adalah penjelasannya : 1) prinsip relevansi merupakan prinsip yang memiliki keterkaitan, bahan ajar harus sesuai dengan standar kompetensi dan kompetensi dasar, 2) prinsip konsistensi adalah prinsip kesesuaian, maksudnya jika kompetensi dasar yang akan dikuasai ada empat maka bahan ajar yang akan digunakan harus sama, 3) prinsip kecukupan maksudnya ialah bahan ajar harus bisa mencukupi untuk membantu siswa agar bisa mencapai suatu tujuan pembelajaran yang diharapkan, bahan ajar juga tidak boleh terlalu sedikit materinya sebab siswa akan merasa sulit untuk mempelajarinya karena keterbatasan materi sedangkan jika materi terlalu banyak juga akan membutuhkan waktu dan tenaga maka pembelajaran tidak akan efisien (Romansyah, 2016). Karakteristik bahan ajar ialah untuk menyusun harus disesuaikan berdasarkan karakteristik serta kebutuhan siswa, untuk melihat dan mengetahui kualitas dan layak digunakannya bahan ajar bisa dilihat sesuai tiga aspek yang mengacu kepada standar penilaian oleh Badan Standar Nasioanal Pendidikan (Khulsum et al., 2018).

Komik ialah sebuah karya seni yang berisi planel-planel yang terdapat gambar namun tidak dapat bergerak dan disusun secara terstruktur dalam bentuk sebuah cerita, dan dalam komik tersebut terdapat sebuah dialog antar tokoh-tokoh (Siregar \& Melani, 2019). Komik sangat bisa digunakan dalam menyampaikan sebuah informasi serta mudah dimengerti, sebuah komik mengkombinasikan gambar serta tulisan yang dibuat dalam sebuah alur cerita yang dapat memberikan pengetahuan agar mudah dalam memahaminya. Komik ialah sebuah buku yang efektif dalam pembelajaran karena di dalamnya ada gambar, teks serta alur cerita (Kusuma Putra \& Yasa, 2019). Buku komik juga berisikan alur cerita yang sederhana 
serta mudah dipahami sehingga buku komik bisa disukai oleh anak-anak Sekolah Dasar atau orang dewasa. Menurut penjelasan di atas dapat peneliti simpulkan bahwa komik ialah karya seni yang dibuat menjadi beberapa planelplanel yang disusun secara teratur berisi gambar serta tulisan yang membentuk sebuah alur cerita yang sederhana dan mudah untuk dimengerti sehingga anak-anak ataupun orang dewasa menyukainya.

Karakteristik komik memiliki cerita yang bersambung dan ceritanya bersifat humor atau menghibur para pembacanya (Nugraheni, 2017). Komik memiliki kelebihan yaitu dalam penyajian cerita secara visual dan cerita yang menarik, dan membuat pembaca merasa ingin terus membacanya sampai selesai, selain mempunyai kelebihan komik juga memiliki kelemahan yaitu proses pembuatannya membutuhkan waktu yang relatif lama, penggunaan sumber belajar terbatas hanya pada materi satuan berat.

Matematika ialah ilmu pengetahuan yang memiliki bagian untuk menciptakan masyarakat yang cerdas, berpikir kritis, dan dapat berpikir logis (Syahputri, 2018). Muatan matematika lebih menekankan pada konsepkonsep (Melinda Rismawati, 2018). Pembelajaran matematika tidak hanya memberikan informasi yang berisi konsep matematika, namun berfokus pada pengembangan keterampilan yang akan dibutuhkan anak dalam memecahkan permasalahan (Azizah et al., 2018). Pemahaman terhadap konsep matematika seharusnya sudah dimiliki oleh semua siswa agar bisa menyelesaikan permasalahannya sendiri dan bisa menerapkan di kehidupan sehari-hari siswa.

Menurut penjelasan di atas maka dapat peneliti simpulkan matematika merupakan ilmu pengatahuan yang memberikan pemahaman mengenai konsep dan melatih kemampuan siswa dalam memecahkan permasalahan matematika.

SDN Pejaten Timur 18 pagi sudah menggunakan kurikulum 2013 sebagai acuan untuk kegiatan belajar mengajar, namun pembelajaran matematika di kelas II masih menerapkan metode pembelajaran konvensional yaitu di mana siswa hanya mendengarkan dan melihat penjelasan dari guru saja (teacher center). Kegiatan pembelajaran menggunakan zoom meeting ternyata banyak siswa yang merasa jenuh dan bosan dalam belajar. Pembelajaran melalui zoom meeting sangat monoton, sebab tidak adanya bahan ajar yang menyenangkan hanya berfokus pada buku tematik terpadu serta harus ada bimbingan dari orang tua siswa.

Siswa merasakan kesulitan dalam memahami materi satuan berat karena materi yang ada di buku tematik terpadu terbatas dan sudah teritegrasi dengan tema sehingga siswa tidak paham untuk mengerjakan soal-soal khususnya materi satuan berat dan buku tematik kurang dalam memberikan contohcontoh soal pada halaman 105 dan halaman 155. Media pembelajaran yang dipakai saat pembelajaran daring yaitu berupa google classroom, google form, video yang bersumber dari youtube, dan padlet. Sumber belajar yang digunakan yaitu buku siswa dan buku guru tematik terpadu kurikulum 2013 kelas II 
Sekolah Dasar khusunya materi satuan berat, tema 7 merwat hewan dan tumbuhan.

Bersumber dari hasil studi pendahuluan maka dapat disimpulkan bahwa permasalahan yang ada pada pembelajaran matematika ialah pembelajaran konvensional, kurangnya pemahaman teori, contoh-contoh dan soal-soal materi satuan berat, siswa merasa kurang minat dalam belajar muatan matematika pada meteri satuan berat sehingga tujuan pembelajaran yang diharapkan belum bisa tercapai. Penggunaan bahan ajar yang masih sederhana sehingga siswa merasa pembelajaran matematika adalah pembelajaran yang monoton, menjenuhkan dan siswa merasa sulit dalam memahami materi karena terintegrasi dengan tema. Akibat dari itu siswa sering mengumpulkan tugas dengan melebihi jangka waktu yang telah ditentukan oleh guru.

Berdasarkan dari hasil studi tersebut maka peneliti ingin mengembangkan bahan ajar berbentuk komik matematika pada materi satuan berat. Penggunaan bahan ajar ini diharapkan dapat menambah minat belajar siswa agar lebih meningkat lagi dan pembelajaran matematika lebih menarik dan bisa tercapainya tujuan kegiatan belajar mengajar dikelas. Penelitian ini ditunjang dengan penelitian terdahulu yaitu, Penelitian yang berjudul Development of Mathematics Learning Media E-Comic Based on Flip Bool Maker to Increase the Critical Thinking Skill and Character of Jurnior High School Students, yang diteliti oleh Raisman dan Aghnita Siska Pramadyasari (2018) penelitian ini menunjukan hasil yang baik dalam penggunaan komik elektronik dan sangat efektif saat digunakan dan dapat meningkatkan keterampilanketerampilan serta dapat meningkatkan juga dalam berpikir kritis kepada siswa saat belajar matematika. Penelitian selanjutnya dengan judul penelitian pengembangan Bahan Ajar Berbasis MATCOM (Mathematical Comic) pada Materi Bangun Datar Untuk Meningkatkan Pemahaman Matematis Peserta Didik yang dilakukan Sholekan (2019), hasil penelitian akhir tersebut bahan ajar yang sudah dikembangkan menghasilkan nilai yang sangat layak, serta memikat dan bisa meningkatkan pemahaman pada siswa. Keberhasilan dalam penelitian sebelumnya menjadikan acuan dilaksanakannya penelitian ini.

\section{METODE PENELITIAN}

Penelitian ini peneliti menggunakan metode $\mathrm{RnD}$ (Research and Development) model pengembangan Borg and Gall dalam (Sugiyono, 2012) menyatakan bahwa penelitian pengembangan ialah salah satu proses yang digunakan dalam mengembangkan dan memvalidasi suatu produk yang dikembangkan oleh peneliti untuk pendidikan (Nova \& Yunianta, 2018). Penelitian ini diuji untuk bisa menyempurnakan produk yang sudah dibuat, produk yang akan dikembangkan oleh peneliti yaitu bahan ajar komik matematika materi satuan berat. Produk diuji untuk melihat dan mendapatkan hasil keefektivan dalam menggunakan bahan ajar di kelas. Komik matematika materi satuan berat ini diuji dalam tiga tahapan, yaitu 1) Uji ahli oleh ahli disain komik, ahli bahasa, ahli materi, dan ahli pembelajaran. Hasil dari validasi disain produk ini digunakan untuk melihat dan acuan 
untuk kelayakan dari produk yang peneliti buat. Ada beberapa kriteria untuk memvalidasi produk sebagai berikut: a) Memiliki wawasan tentang karakteritik pembelajaran matematika, b) Memiliki wawasan dibidang bahasa, c) Memiliki pengalaman dalam mendesain dan merancang bahan ajar, d) Memiliki latar belakang pendidikan minimal S1/S2, e) Guru yang masih aktif mengajar dikelas II SDN Pejaten Timur 18 Pagi Jakarta Selatan, f) Siswa/i kelas II SDN Pejaten Timur 18 Pagi Jakarta Selatan. Memvalidasi produk ini memiliki tujuan agar bisa mendapatkan data berupa penilaian, komentar dan saran validator untuk bahan ajar yang dibuat sehingga mengetahui layak atau tidak produk yang dibuat oleh peneliti. Berikut ialah instrumen validasi ahli terhadap produk bahan ajar komik matematika materi satuan berat:

a. Instrumen lembar validasi ahli desain

Tabel 1 Kisi-kisi lembar validasi ahli disain

\begin{tabular}{|c|c|c|}
\hline $\begin{array}{c}\text { Aspek } \\
\text { Penilaian }\end{array}$ & Indikator & $\begin{array}{c}\text { Jumlah } \\
\text { Butir }\end{array}$ \\
\hline \multirow{9}{*}{$\begin{array}{c}\text { Tampilan } \\
\text { dari } \\
\text { Komik } \\
\text { dan video }\end{array}$} & $\begin{array}{l}\text { Teks dapat terbaca } \\
\text { dengan baik }\end{array}$ & 1 \\
\hline & $\begin{array}{l}\text { Memilih background } \\
\text { yang sesuai }\end{array}$ & 1 \\
\hline & $\begin{array}{l}\text { Jenis huruf dan ukuran } \\
\text { teks yang sesuai }\end{array}$ & 1 \\
\hline & Warna yang bervariasi & 1 \\
\hline & $\begin{array}{l}\text { Gambar pendukung } \\
\text { yang cocok }\end{array}$ & 1 \\
\hline & Sajian animasi & 1 \\
\hline & Sajian video & 1 \\
\hline & $\begin{array}{l}\text { Suara bisa terdengan } \\
\text { dengan jelas }\end{array}$ & 1 \\
\hline & $\begin{array}{ll}\text { Kelengakapan } & \text { dan } \\
\text { kejelasan materi } & \end{array}$ & 1 \\
\hline
\end{tabular}

\begin{tabular}{|l|l|c|}
\hline $\begin{array}{c}\text { Aspek } \\
\text { Penilaian }\end{array}$ & \multicolumn{1}{|c|}{ Indikator } & $\begin{array}{c}\text { Jumlah } \\
\text { Butir }\end{array}$ \\
\hline & $\begin{array}{l}\text { Kejelasan petunjuk } \\
\text { penggunaan }\end{array}$ & 1 \\
\hline $\begin{array}{l}\text { Pemogra } \\
\text { man } \\
\text { bahan } \\
\text { ajar }\end{array}$ & $\begin{array}{l}\text { Penggunaan dalam } \\
\text { memasukan barcode }\end{array}$ & 1 \\
\cline { 2 - 3 } & $\begin{array}{l}\text { Kemudahan dalam } \\
\text { menggunakan bahan } \\
\text { ajar }\end{array}$ & 1 \\
\hline \multicolumn{3}{|c|}{ Jumlah } \\
\hline
\end{tabular}

b. Instrumen lembar validasi ahli bahasa

Tabel 2 Kisi-kisi lembar validasi ahli bahasa

\begin{tabular}{|l|l|c|}
\hline \multicolumn{1}{|c|}{$\begin{array}{c}\text { Aspek } \\
\text { Penilaian }\end{array}$} & \multicolumn{1}{|c|}{ Indikator } & $\begin{array}{c}\text { Jumlah } \\
\text { Butir }\end{array}$ \\
\hline Lugas & $\begin{array}{l}\text { Ketepatan dalam } \\
\text { struktur kalimat }\end{array}$ & 1 \\
\cline { 2 - 3 } & $\begin{array}{l}\text { Keefektifan sebuah } \\
\text { kalimat }\end{array}$ & 1 \\
\cline { 2 - 3 } & $\begin{array}{l}\text { Kebakuan sebuah } \\
\text { istilah }\end{array}$ & 1 \\
\hline $\begin{array}{l}\text { Komunik } \\
\text { atif }\end{array}$ & $\begin{array}{l}\text { Memahami informasi } \\
\text { dan pesan }\end{array}$ & 1 \\
\hline $\begin{array}{l}\text { Dialogis } \\
\text { dan }\end{array}$ & $\begin{array}{l}\text { Kemampuan dalam } \\
\text { memotivasi siswa }\end{array}$ & 1 \\
\cline { 2 - 3 } $\begin{array}{l}\text { Interaktif } \\
\text { Kemampuan untuk } \\
\text { mendorong dalam } \\
\text { kreativitas siswa }\end{array}$ & 1 \\
\hline $\begin{array}{l}\text { Kesesuaia } \\
\text { n dengan } \\
\text { kaidah } \\
\text { bahasa }\end{array}$ & $\begin{array}{l}\text { Ketepatan } \\
\text { bahasa }\end{array}$ & 1 \\
\hline $\begin{array}{l}\text { Kesesuaia } \\
\text { n dan } \\
\text { perkemba } \\
\text { ngan } \\
\text { siswa }\end{array}$ & $\begin{array}{l}\text { Kesesuaian dan } \\
\text { perkembangan } \\
\text { pengetahuan siswa }\end{array}$ & 1 \\
\hline $\begin{array}{l}\text { Pengguna } \\
\text { an istilah, } \\
\text { ikon dan } \\
\text { simbol }\end{array}$ & $\begin{array}{l}\text { Kesesuaian ejaan dan } \\
\text { penggunaan istilah }\end{array}$ & $\begin{array}{l}\text { Konsistensi } \\
\text { penggunaan simbol } \\
\text { atau istilah }\end{array}$ \\
\hline \begin{tabular}{l} 
Jumlah \\
\hline
\end{tabular} & 1 \\
\hline
\end{tabular}

c. Instrumen lembar validasi ahli materi Tabel 3 Kisi-kisi lembar validasi ahli materi 


\begin{tabular}{|c|c|c|}
\hline $\begin{array}{c}\text { Aspek } \\
\text { Penilaian }\end{array}$ & Indikator & $\begin{array}{l}\text { Jumlah } \\
\text { Butir }\end{array}$ \\
\hline \multirow[t]{3}{*}{$\begin{array}{l}\text { Pembelaja } \\
\text { ran }\end{array}$} & $\begin{array}{ll}\text { Kesesuaian } & \text { materi } \\
\text { dengan KD } & \\
\end{array}$ & 1 \\
\hline & $\begin{array}{l}\text { Materi disajiakan } \\
\text { dengan sistematis }\end{array}$ & 1 \\
\hline & $\begin{array}{l}\text { Ketepatan struktur } \\
\text { sebuah kalimat dan } \\
\text { bahasa yang mudah } \\
\text { dipahami oleh } \\
\text { pengguna bahasa }\end{array}$ & 1 \\
\hline \multirow[t]{8}{*}{ Isi Materi } & $\begin{array}{lr}\text { Materi } & \text { disesuaikan } \\
\text { dengan } & \text { yang } \\
\text { dirumuskan } & \end{array}$ & 1 \\
\hline & $\begin{array}{lr}\text { Materi } & \text { disesuaikan } \\
\text { dengan } & \text { tingkat } \\
\text { kemampuan siswa }\end{array}$ & 1 \\
\hline & $\begin{array}{l}\text { Kejelasan } \\
\text { satuan berat }\end{array}$ & 1 \\
\hline & $\begin{array}{l}\text { Materi berkaitan } \\
\text { dengan sub materi } \\
\text { yang di bahas }\end{array}$ & 1 \\
\hline & $\begin{array}{l}\text { Materi jelas dan } \\
\text { spesifik }\end{array}$ & 1 \\
\hline & $\begin{array}{lr}\text { Gambar } & \text { yang } \\
\text { digunakan } & \\
\text { disesuaikan } & \text { dengan } \\
\text { materi } & \\
\end{array}$ & 1 \\
\hline & $\begin{array}{l}\text { Contoh soal sesuai } \\
\text { dengan materi }\end{array}$ & 1 \\
\hline & Jumlah & 10 \\
\hline
\end{tabular}

d. Instrumen lembar validasi ahli Pembelajaran

Tabel 4 Kisi-kisi lembar validasi ahli pembelajaran

\begin{tabular}{|c|c|c|}
\hline $\begin{array}{c}\text { Aspek } \\
\text { Penilaian }\end{array}$ & Indikator & $\begin{array}{c}\text { Jumlah } \\
\text { Butir }\end{array}$ \\
\hline \multirow{4}{*}{$\begin{array}{l}\text { Kesesuaia } \\
\mathrm{n} \text { Materi } \\
\text { dengan } \\
\text { KI, KD, } \\
\text { Indikator } \\
\text { dan } \\
\text { Tujuan } \\
\text { dari } \\
\text { pembelaja } \\
\text { ran }\end{array}$} & $\begin{array}{l}\text { Kesesuain sebuah } \\
\text { materi dengan KI }\end{array}$ & 1 \\
\hline & $\begin{array}{l}\text { Kesesuaian sebuah } \\
\text { materi dengan KD }\end{array}$ & 1 \\
\hline & $\begin{array}{ll}\text { Kesesuaian } & \text { sebuah } \\
\text { materi } & \text { dengan } \\
\text { Indikator } & \end{array}$ & 1 \\
\hline & $\begin{array}{ll}\text { Kesesuaian } & \text { sebuah } \\
\text { materi dengan } & \text { Tujuan } \\
\text { pembelajaran } & \end{array}$ & 1 \\
\hline
\end{tabular}

\begin{tabular}{|l|l|c|}
\hline $\begin{array}{c}\text { Aspek } \\
\text { Penilaian }\end{array}$ & \multicolumn{1}{|c|}{ Indikator } & Jumlah \\
\hline $\begin{array}{l}\text { Aspek } \\
\text { Pembelaja } \\
\text { ran }\end{array}$ & $\begin{array}{l}\text { Kesesuaian bahan ajar } \\
\text { dengan kebutuhan } \\
\text { pembelajaran }\end{array}$ & 1 \\
\cline { 2 - 3 } & $\begin{array}{l}\text { Bahan ajar } \\
\text { mempermudah guru } \\
\text { dalam mengajar }\end{array}$ & 1 \\
\cline { 2 - 3 } & $\begin{array}{l}\text { Bahan ajar dapat } \\
\text { melatih siswa untuk } \\
\text { belajar mandiri }\end{array}$ & 1 \\
\hline $\begin{array}{l}\text { Kelayaka } \\
\text { n Bahan } \\
\text { Ajar }\end{array}$ & $\begin{array}{l}\text { Bahan ajar yang bisa } \\
\text { digunakan untuk } \\
\text { jangka panjang }\end{array}$ & 1 \\
\cline { 2 - 3 } $\begin{array}{l}\text { Bahan ajar bisa } \\
\text { memberikan konsep, } \\
\text { contoh dan soal-soal } \\
\text { materi satuan berat }\end{array}$ & 1 \\
\cline { 2 - 3 } & $\begin{array}{l}\text { Kemudahan } \\
\text { penggunaan bahan ajar } \\
\text { komik memakai } \\
\text { barcode }\end{array}$ & 1 \\
\hline & \begin{tabular}{l} 
Jumlah \\
\hline
\end{tabular} \\
\hline
\end{tabular}

2) Uji coba produk dengan 9 siswa; 3) Uji pemakaian produk dengan 29 siswa dalam satu kelas di kelas II Sekolah Dasar, berikut ialah kisi-kisi instrumen lembar validasi siswa:

Tabel 5 Kisi-kisi lembar validasi siswa

\begin{tabular}{|c|l|c|}
\hline $\begin{array}{c}\text { Aspek } \\
\text { Penilaian }\end{array}$ & \multicolumn{1}{|c|}{ Indikator } & $\begin{array}{c}\text { Jumlah } \\
\text { Butir }\end{array}$ \\
\hline $\begin{array}{c}\text { Bahan } \\
\text { Ajar }\end{array}$ & $\begin{array}{l}\text { Kemudahan untuk } \\
\text { menggunakan komik }\end{array}$ & 1 \\
\cline { 2 - 3 } & $\begin{array}{l}\text { Kejelasan mengenai } \\
\text { petunjuk penggunaan } \\
\text { komik }\end{array}$ & 1 \\
\cline { 2 - 3 } & $\begin{array}{l}\text { Kejelasan dalam materi } \\
\text { Kesesuaian bahasa } \\
\text { dengan pemahaman } \\
\text { siswa }\end{array}$ & 1 \\
\cline { 2 - 3 } & $\begin{array}{l}\text { Kesesuaian gambar dan } \\
\text { video dengan materi }\end{array}$ & 1 \\
\cline { 2 - 3 } $\begin{array}{l}\text { Ketepatan dalam } \\
\text { memilih background dan } \\
\text { teks }\end{array}$ & 1 \\
\hline
\end{tabular}




\begin{tabular}{|c|l|c|}
\hline $\begin{array}{c}\text { Pembelaj } \\
\text { aran }\end{array}$ & $\begin{array}{l}\text { Kemampuan belajar } \\
\text { mandiri }\end{array}$ & 1 \\
\cline { 2 - 3 } & $\begin{array}{l}\text { Meningkatkan } \\
\text { pengetahaun dan } \\
\text { wawasan siswa }\end{array}$ & 1 \\
\cline { 2 - 3 } $\begin{array}{l}\text { Menciptakan rasa senang } \\
\text { untuk siswa }\end{array}$ & 1 \\
\cline { 2 - 3 } & $\begin{array}{l}\text { Membantu, memahami } \\
\text { materi }\end{array}$ & $\mathbf{1 0}$ \\
\hline
\end{tabular}

Tahap-tahapan penelitian ini ialah sebagai berikut: 1) Potensi Masalah, tahapan ini digunakan peneliti untuk melihat permasalahan yang ada di kelas, setelah mendapatkan data dan informasi maka hasilnya akan dianalisis oleh peneliti agar bisa mendapatkan potensi yang bisa menyelesaikan permasalahan, 2) Pengumpulan data, tahap ini untuk mengumpulkan data-data serta informasi dari hasil observasi kegiatan pembelajaran serta hasil wawancara bersama guru dan siswa, 3) Desian produk, tahapan desain produk ini menjelaskan pembuatan produk yang akan dikembangkan dan disesuaikan dengan karakteristik siswa, 4) Validasi produk, tahap validasi produk ini untuk menilai produk yang sudah dibuat oleh peneliti dan dinilai oleh para ahli di bidang disain, bahasa, materi dan pembelajaran, 5) Revisi produk, revisi produk ini dilakukan untuk penyempurnaan produk yang sudah dinilai oleh para ahli agar produk yang dibuat lebih baik dari sebelumnya, 6) Uji coba produk, tahap uji coba produk ini dilakukan di kelas II Sekolah Dasar dengan melibatkan 9 siswa secara heterogen, hasil dari tahap ini bisa memberikan tanggapan terhadap produk yang dibuat, 7) Revisi produk, revisi produk ini dilakukan untuk penyempurnakan produk yang sudah dinilai oleh para ahli agar produk yang dibuat lebih baik dari sebelumnya, 8) Uji coba pemakaian produk, tahapan ini dilakukan di kelas II Sekolah Dasar dengan melibatkan 29 siswa dalam satu kelas dari tahapan uji coba ini peneliti bisa mendapatkan tanggapan dari responden mengenai produk yang dibuat oleh peneliti. 9) Revisi produk, tahapan terakhir pada tahap ini peneliti melakukan perbaikan dan penyempurnaan berdasarkan hasil komentar dan saran saat uji coba pemakaian produk bersama siswa.

Teknik untuk mengumpulkan data pada penelitian dan pengembangan ini yaitu: 1) Wawancara ialah kegiatan tanya jawab antara peneliti dan narasumber yang bertujuan untuk memperoleh informasi (Mandala, 2017), 2) Observasi ialah teknik dalam mengumpulkan data yang dibutuhkan dengan cara melihat kegiatan pembelajaran di kelas (Mugianto, 2017), 3) Kuesioner merupakan sebuah bentuk instrumen untuk mengumpulkan data yang biasanya dilakukan untuk mendapatkan data yang jumlahnya besar (Pranatawijaya \& Priskila, 2019), 4) Dokumentasi ialah data yang berupa foto-foto dan gambar dari hasil penelitian (Anjarsari, 2019).

Teknik dalam menganalisis data pada penelitian dan pengembangan ini yang pakai ada dua teknik yaitu analisis data kualitatif yaitu mengumpulkan data yang akan dideskripsikan atau dijelaskan yang berisikan data dari wawancara, observasi dan hasil kuesioner yang berupa komentar dan saran dari produk yang telah dibuat oleh peneliti, 
sedangkan teknik analisis data kuantitatif yaitu berisikan angka-angka dari skor validasi ahli, uji coba produk, dan uji pemakaian produk. Penelitian ini menggunakan skala likert berbentuk pilihan ganda atau checklist. Skala likert ialah skala yang biasanya dipakai dalam mengukur pendapat dari seseorang untuk menyikapi sebuah fenomena sosial ataupun peristiwa (Pranatawijaya \& Priskila, 2019). Berikut ialah rumusan dan interval skor sebagai berikut:

Rumus :

Presentasi $=\frac{\text { Skor Total }}{\text { Skor Max }} \times 100$

Keterangan:

$\mathrm{P}=$ Tingkat kevalidan

Skor Total $=$ Skor jawaban responden

Skor Max = Skor jawaban tertinggi

Tabel 6. Interval skor analisis data

\begin{tabular}{|c|c|c|}
\hline No & Interval skor & Kategori \\
\hline 1 & $81 \%-100 \%$ & $\begin{array}{c}\text { Sangat } \\
\text { valid }\end{array}$ \\
\hline 2 & $61 \%-80 \%$ & Valid \\
\hline 3 & $41 \%-60 \%$ & $\begin{array}{c}\text { Cukup } \\
\text { valid }\end{array}$ \\
\hline 4 & $21 \%-40 \%$ & $\begin{array}{c}\text { Kurang } \\
\text { valid }\end{array}$ \\
\hline 5 & $0 \%-20 \%$ & $\begin{array}{c}\text { Sangat } \\
\text { kurang } \\
\text { valid }\end{array}$ \\
\hline
\end{tabular}

Menurut kriteria bahan ajar bisa dinyatakan sangat valid saat mendapatkan skor $84-100 \%$ yang diperoleh saat uji validasi oleh validator para ahli, uji produk, dan uji pemakaian produk, jika valid maka tidak perlu untuk melakukan revisi namun jika kriteria yang didapatkan tidak valid maka peneliti harus melakukan revisi kembali sampai mendapatkan hasil yang bisa dinyatakan valid atau sangat valid.

\section{HASIL DAN PEMBAHASAN}

A. Merancang dan membuat bahan ajar komik matematika materi satuan berat

Merancang dan membuat bahan ajar komik matematika materi satuan berat yang bisa digunakan oleh siswa saat pembelajaran supaya minat belajar siswa bisa meningkat dan untuk guru bisa memfasilitasi dan membantu dalam belajar mengajar di kelas.

Desain awal pembuatan bahan ajar komik matematika materi satuan berat dibuat sebuah cerita sederhana dengan menggunakan karakter anak-anak dengan memasukan materi satuan berat dan di lengkapi $Q R$ barcode yang bisa dipindai dan akan muncul sebuah video penjelasan.

Gambar tersebut merupakan produk akhir bahan ajar komik matematika materi satuan berat yang terdiri dari 4 sub bahasan materi satuan berat, 4 sub materi yaitu: Pengertian satuan berat, tangga satuan berat, menimbang berat benda, dan membandingkan berat benda. Adapun gambaran produk akhir bahan ajar komik matematika materi satuan berat yaitu 1) kertas 80 gram; 2) ukuran A5; 3) ketebalan 54 halaman (bolak-balik + cover), jenis huruf SANS SERIF; 4) dengan format pdf; 5) materi satuan berat kelas 2 Sekolah Dasar; 6) software kebutuhan : canva, zepeto, youtube, kinemaster, dan pinterest. 
berikut adalah disain bahan ajar komik matematika materi satuan berat:
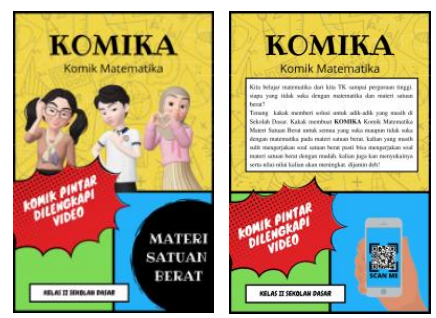

Gambar 1 cover depan dan belakang

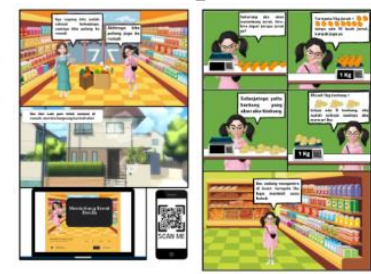

Gambar 2 isi komik

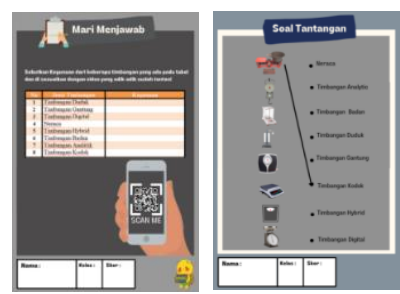

Gambar 3 soal dan tes evaluasi buku

komik

B. Hasil pengembangan bahan ajar komik matematika materi satuan berat

Tahapan sebelumnya telah dilakukan analisis deskripstif pembuatan bahan ajar komik matematika materi satuan berat untuk memperoleh gambar rancangan produk. Sebelum melakukan uji coba produk peneliti melakukan validasi terhadap bahan ajar yang dibuat kepada para ahli untuk mengetahui kelayakan dari produk yang dibuat peneliti. Berikut variabel hasil validasi produk oleh para ahli:

Tabel 7 hasil validasi ahli terhadap produk

\begin{tabular}{|c|c|c|c|c|c|c|}
\hline $\begin{array}{c}\text { Valid } \\
\text { asi } \\
\text { ahli }\end{array}$ & $\begin{array}{c}\text { Desai } \\
\mathbf{n}\end{array}$ & $\begin{array}{c}\text { Baha } \\
\text { sa }\end{array}$ & $\begin{array}{c}\text { Mate } \\
\text { ri }\end{array}$ & $\begin{array}{c}\text { Pemb } \\
\text { elaja } \\
\text { ran }\end{array}$ & $\begin{array}{c}\text { Rata- } \\
\text { rata }\end{array}$ & $\begin{array}{c}\text { Tingkat } \\
\text { kevalida } \\
\text { n }\end{array}$ \\
\cline { 2 - 7 } & $\begin{array}{c}83.33 \\
\%\end{array}$ & $\begin{array}{c}90.00 \\
\%\end{array}$ & $\begin{array}{c}90.00 \\
\%\end{array}$ & $\begin{array}{c}92.00 \\
\%\end{array}$ & $\begin{array}{c}88.83 \\
\%\end{array}$ & $\begin{array}{c}\text { Sangat } \\
\text { valid }\end{array}$ \\
\hline
\end{tabular}

Setelah melakukan validasi ahli untuk produk yang dikembangkan peneliti mendapatkan hasil $88.33 \%$ maka bahan ajar komik matematika materi satuan berat dinyatakan sangat valid atau tidak layak untuk digunakan di kelas dalam proses belajar mengajar.

Selanjutnya peneliti melakukan uji coba produk kepada siswa secara skala kecil yaitu 9 siswa yang heterogen (terdiri dari 3 siswa yang memiliki kemampuan yang rendah, 3 siswa yang memiliki kemampuan sedang dan 3 siswa memiliki kemampuan tinggi). Siswa diberikan buku komik saat sebelum uji coba dimulai agar bisa melihat terlebih dahulu, siswa diberikan arahan cara penggunaan bahan ajar komik matematika materi satuan berat oleh peneliti, lalu siswa melakukan uji produk dengan guru dan siswa yaitu melakukan pembelajaran setelah melakukan uji coba, siswa diminta untuk mengisi kuesioner penilaian produk. Berikut adalah hasil uji coba produk skala kecil dengan skala likert:

Tabel 8 Data Statistik Hasil Uji Coba Produk Skala Kecil

\begin{tabular}{|c|c|c|c|c|c|}
\hline $\begin{array}{c}\text { Uji } \\
\text { Coba }\end{array}$ & $\begin{array}{c}\text { Juml } \\
\text { ah } \\
\text { Siswa }\end{array}$ & Nilai & $\begin{array}{l}\text { Nilai } \\
\text { Max }\end{array}$ & $\begin{array}{l}\text { Rata- } \\
\text { rata }\end{array}$ & $\begin{array}{c}\text { Tingkat } \\
\text { Kevalidan }\end{array}$ \\
\hline Produk & 9 & 408 & 50 & $90.67 \%$ & $\begin{array}{c}\text { Sangat } \\
\text { valid }\end{array}$ \\
\hline
\end{tabular}


Hasil dari presentase menunjukkan hasil penilaian uji coba produk jika dihitung pencapaian bahan ajar komik matematika materi satuan berat mendapatkan presentase kevalidan $81.60 \%$. Hasil dari penilaian ini di konversikan dengan interval skor analisis data, tingkat pencapaian komik matematika materi satuan berat berada pada kualifikasi sangat valid.

Setelah peneliti melakukan uji coba produk dan mendapatkan hasil yang sangat valid maka peneliti melalukan penyempurnaan produk. Setelah melakukan revisi produk maka peneliti melakukan tahap selanjutnya yaitu uji coba pemakaian kepada 29 siswa atau satu kelas II SDN Pejaten Timur 18 pagi Jakarta Selatan.

Tabel 9 Data Statistik Hasil Uji Coba Pemakaian

\begin{tabular}{|c|c|c|c|c|c|}
\hline $\begin{array}{c}\text { Uji Coba } \\
\begin{array}{c}\text { Pemakaia } \\
\text { n }\end{array}\end{array}$ & $\begin{array}{c}\text { Jumla } \\
\text { h } \\
\text { Siswa }\end{array}$ & $\begin{array}{c}\text { Nila } \\
\mathbf{i}\end{array}$ & $\begin{array}{c}\text { Nila } \\
\mathbf{i} \\
\mathbf{M a}\end{array}$ & $\begin{array}{c}\text { Rata- } \\
\text { rata }\end{array}$ & $\begin{array}{c}\text { Tingkat } \\
\text { Kevalida } \\
\mathbf{n}\end{array}$ \\
\cline { 2 - 6 } & 29 & 129 & 145 & 89.38 & $\begin{array}{c}\text { Sangat } \\
\text { Valid }\end{array}$ \\
\hline
\end{tabular}

Setelah peneliti melalukan uji coba pemakaian kepada siswa untuk melihat keefektifan bahan ajar komik matematika materi satuan berat, produk bahan ajar ini mendapatkan ahsil $89.38 \%$ dikatakan sangat valid atau sangat efektif sehingga tidak dilakukan uji coba ulang kepada siswa lagi. Bahan ajar komik matematika materi satuan berat ini bisa digunakan guru sebagai sumber belajar bagi siswa kelas II dan guru di SDN Pejaten Timur 18 pagi Jakarta Selatan pada materi satuan berat.

\section{SIMPULAN}

Bahan ajar komik matematika materi satuan berat ini untuk membuat siswa menjadi lebih minat untuk belajar, bahan ajar sebelum diberikan kepada siswa peneliti melakukan validasi produk kepada para ahli, uji coba produk dan uji coba pemakaian produk ini agar menghasilkan bahan ajar yang layak untuk digunakan siswa saat pembelajaran dikelas.

Bahan ajar ini mendapatkan tingkat kelayakan pada tahap validasi ahli mendapatkan rata-rata nilai $88.33 \%$, tahap uji coba produk yang dibatasi respondennya yaitu 9 siswa mendapatkan nilai dengan rata-rata $90.67 \%$, dan saat uji pemakaian produk kepada satu kelas sebanyak 29 siswa bahan ajar ini mendapatkan hasil nilai dengan rata-rata $89.38 \%$, maka bahan ajar ini mendapatkan tingkat pencapaian komik matematika materi satuan berat berada pada kualifikasi sangat valid.

\section{DAFTAR RUJUKAN}

Anjarsari, E. (2019). Faktor Permasalahan Pendekatan Saintifik 5M Dalam Pembelajaran Matematika Di Sma. Vygotsky, 1(1), https://doi.org/10.30736/vj.v1i1.88

Arsanti, M. (2018). Pengembangan Bahan Ajar Mata Kuliah Penulisan Kreatif Bermuatan Nilai-Nilai Pendidikan Karakter Religius Bagi Mahasiswa Prodi Pbsi, Fkip, Unissula. KREDO : Jurnal Ilmiah Bahasa Dan Sastra, 1(2), 71-90. https://doi.org/10.24176/kredo.v1i2.2107

Azizah, M., Sulianto, J., \& Cintang, N. (2018). Analisis Keterampilan Berpikir Kritis Siswa Sekolah Dasar pada Pembelajaran Matematika Kurikulum 2013. Jurnal Penelitian Pendidikan, 35(1), 61-70. https://doi.org/10.15294/jpp.v35i1.13529 
Khulsum, U., Hudiyono, Y., \& Sulistyowati, E. D. (2018). Pengembangan Bahan Ajar Menulis Cerpen Dengan Media Storyboard. Diglosia, 1(1), 1-12.

Kusuma Putra, G. L. A., \& Yasa, G. P. P. A. (2019). Komik Sebagai Sarana Komunikasi Promosi Dalam Media Sosial. Jurnal Nawala Visual, 1(1), 1-8. https://doi.org/10.35886/nawalavisual.v1i 1.1

Lestari, I. (2018). Pengembangan Bahan Ajar Matematika dengan Memanfaatkan Geogebra untuk Meningkatkan Pemahaman Konsep. GAUSS: Jurnal Pendidikan Matematika, I(1), 26. https://doi.org/10.30656/gauss.v1i1.634

Mandala, J. P. (2017). Jurnal Pendidikan Mandala 189. 2(2), 189-193.

Melinda Rismawati, A. S. R. H. (2018). Analisis Kemampuan Pemahaman Konsep Matematika Mahasiswa PGSD STKIP Persada Khatulistiwa Sintang. Jurnal Pendidikan Dasar PerKhasa, 4(April),

1.

http://ieeeauthorcenter.ieee.org/wp-

content/uploads/IEEE-Reference-

Guide.pdf\%0Ahttp://wwwlib.murdoch.ed u.au/find/citation/ieee.html\%0Ahttps://do i.org/10.1016/j.cie.2019.07.022\%0Ahttps ://github.com/ethereum/wiki/wiki/WhitePaper\%0Ahttps://tore.tuhh.de/handle/114 20

Mugianto. (2017). Teks Laporan Hasil Observasi Model Pembelajaran Berbasis Proyek Siswa Kelas X SMA. Jurnal Ilmu Budaya, 1(4), 353-366. http://dx.doi.org/10.30872/ilmubudaya.v $1 \mathrm{i} 4.769$

Nova, T., \& Yunianta, H. (2018). Pengembangan Media Komik Matematika pada Materi Pecahan untuk Siswa Kelas V Sekolah Dasar. 5(1), 7990.

Nugraheni, N. (2017). Penerapan Media Komik Pada Pembelajaran Matematika Di Sekolah Dasar. Refleksi Edukatika: Jurnal Ilmiah Kependidikan, 7(2), 111117. https://doi.org/10.24176/re.v7i2.1587

Nurdyansyah, \& Mutala'liah, N. (2016). Pengembangan Bahan Ajar Modul Ilmu Pengetahuan Alambagi Siswa Kelas IV Sekolah Dasar. Program Studi Pendidikan Guru Madrasa Ibtida'iyah Fakultas Agama Islam Universitas Muhammadiyah Sidoarjo, 41(20), 1-15. http://jurnal.unswagati.ac.id/index.php/lo gika/article/download/145/97

Pranatawijaya, V. H., \& Priskila, R. (2019). Pengembangan Aplikasi Kuesioner Survey Berbasis Web Menggunakan Skala Likert dan Guttman. 5(November), 128137. https://doi.org/10.34128/jsi.v5i2.185

Romansyah, K. (2016). Pedoman Pemilihan dan Penyajian Bahan Ajar Mata Pelajaran Bahasa dan Sastra Indonesia. Jurnal Logika, XVII(2), 59-66. http://jurnal.unswagati.ac.id/index.php/lo gika/article/download/145/97

Siregar, H. F., \& Melani, M. (2019). Perancangan Aplikasi Komik Hadist Berbasis Multimedia. Jurnal Teknologi Informasi, $2(2), \quad 113$. https://doi.org/10.36294/jurti.v2i2.425

Syahputri, N. (2018). Rancangan Bangun Media Pembelajaran Matematika Sekolah Dasar Kelas 1 Menggunakan Metode Demonstrasi. JSIK (Jurnal Sistem Informasi Kaputama), 2(1), 89-95. 